\title{
EDUARDO MILÁN
}

\section{Una "nueva" generación en el horizonte de lo probable}

La última gran generación poética latinoamericana es la que puede denominarse con el nombre de "maestros herederos de la vanguardia". Una generación que no puede medirse con el eje diacrónico-histórico, sino, mejor, a partir de una actitud programática clara: la actitud crítica frente al lenguaje poético. Una generación que se mira en el espejo de Rubén Darío, lo reverencia y, a la vez, lo quiebra. Bajo el nombre de "maestros herederos de la vanguardia" distingo dos grupos bien definidos: el primero, inmediato a la ruptura del maestro modernista, integrado por Vicente Huidobro, César Vallejo, Pablo Neruda y Oliverio Girondo. El segundo, un grupo de dos, tardío respecto a la avanzada modernista, pero igualmente ejemplár: Octavio Paz y José Lezama Li ma. Distintas coordenadas mueven las obras de estos poetas pero su práctica está unificada por el abandono de la encrucijada neorromántica, esto es, por el reglamento del "ego lírico". El yo poético, a partir del momento de la puesta en escena de la hiperconciencia frente al lengua je, pasa al lugar de la neutralidad. En la poesía de estos "herederos" el titular del poema, otrora hablante ficticio, desaparece bajo la masa opaca del lenguaje. Ya nadie habla más que el lenguaje.

En términos teóricos la herencia que reciben de la vanguardia es el abandono de la práctica del poema como correlato inmediato de una "idea" de la realidad. En otros términos: la mímesis o práctica de la norma es abandonada por una poética de la invención, una poética que hace surgir al texto prácticamente "de la nada". El texto se funda en su propia experiencia, como rompiendo con toda forma de tradición canónica y fundando una nueva forma de relación con la herencia: el diálogo intertextual. Ahora los textos dejan de lado toda pretensión epigonal y se instalan como presencias inaugurales. Dos casos ejemplares: Altazor de Vicente Huidobro y Blanco de Octavio Paz. El habla de Altazor nace a los treinta y tres años, a la edad de la muerte de Cristo: es un habla que nace fundada en la muerte de una tradición, la judeo-cristiana. Blanco de Octavio Paz abre con la "simiente latente" del comienzo. Son dos textos que reconocerán la tradición precisamente en el momento en que la inventen. Los otros ejemplos no son menos relevantes. Trilce, de César Vallejo, representa el momento de mayor ruptura sintáctica que registra la poesia latinoamericana del siglo. Una sintaxis que se desencadena como 
desenmascaramiento de la lógica aristotélico-cartesiana que funda la idea de Poder en Occidente. El texto de Vallejo no se entiende: la misión está cumplida. Sólo puede percibirse una conciencia en lucha casi corporal con el lenguaje poético, una conciencia fragmentada que dialoga con la imagen que Mallarmé otorgara a su aventura más radical: las "subdivisiones prismáticas de la idea" de Un coup de dés. El texto de Vallejo no es una "obra abierta", en la medida en que el lector no puede reordenar el desastre: hay astillas que el lector recibe en su cuerpo perceptivo con impavidez. Neruda entra a la materia de las Residencias como un iniciado que oculta sus fuentes iniciáticas. Pretende dar cuenta de una aventura sin antecedentes en la lírica occidental: su lenguaje titubea, se dice y se desdice, rompe directamente el diálogo con los referentes del mundo para pri vilegiar un único referente: el signo mismo, el que no puede hablar, el "que no dice", pero que es testigo del mundo mudo de las cosas, al convertirse en una cosa más. En un sentido sartreano, las palabras están "en situación" poética: se han vuelto cosas dentro del texto.

Oliverio Girondo construye sus textos a partir del impulso propio del verso: largas tiradas que dependen de la respiración del poema y que ya no pueden obedecer a ningún canon establecido. Sus poemas no tienèn tema, ni siquiera el gran tema del comienzo. Todo origen -aun el origen del poema- está perdido. Sólo queda la performance de un téxto que ha nacido y que morirá ahí, en la página. Y lo que es pérdida de oriğen en Girondo es pérdida de centro en Lezama. El barroco, el amaneramiento y la suntuosidad de la metáfora señalan un lugar vacío: el mundo, que no puede ser ordenado ni siquiera con el fingimiento textual. Lo que queda es el espectáculo metafórico, la ligazón ocasional de dos imágenes pa ra dar cuenta de un caos. Lezama acepta el caos; dlo acepta el caos a él? Su obra es, todavía, indescifrable.

¿Cuál es el legado de esta actitud frente al lenguaje? En primer lugar, un soslayar el área semántica como definidora del suceso poético. El significante se ha privilegiado de tal manera que, de ahí en adelante, no será posible relegarlo a su sola condición material. Es más: ahora es el significante el que creará al significado. Ya nó será posible dar cuenta de las tormentas del espíritu sin dar, a la vez, cuenta de los tormentos del lenguaje. El lenguaje se exhibe como condición sine qua non o piedra de toque para la poesía. Un lenguaje en plena exhibición, sí. Un lenguaje narcicista, sí. Pero, tambiên, el reconocimiento y, más aún, la fundación en la poesía latinoamericana de un eje dialógico que charla con lo mejor de la tradición poética occidental: la poética provenzal y Dante, el lenguaje pre-verbal de San Juan de la Cruz y Luis de Góngora, la metafísica corporal de John Donne y la pureza materialista de Mallarmé. Un lenguaje que dialoga con los fundadores de la concretud. 